San Jose State University

SJSU ScholarWorks

Master's Theses

Master's Theses and Graduate Research

1999

\title{
Genetic differences between two growth-forms of Lithophyllum margaritae
}

Timothy Nicholas Schaeffer

San Jose State University

Follow this and additional works at: https://scholarworks.sjsu.edu/etd_theses

\section{Recommended Citation}

Schaeffer, Timothy Nicholas, "Genetic differences between two growth-forms of Lithophyllum margaritae" (1999). Master's Theses. 1896.

DOI: https://doi.org/10.31979/etd.v3a4-up47

https://scholarworks.sjsu.edu/etd_theses/1896

This Thesis is brought to you for free and open access by the Master's Theses and Graduate Research at SJSU ScholarWorks. It has been accepted for inclusion in Master's Theses by an authorized administrator of SJSU ScholarWorks. For more information, please contact scholarworks@sjsu.edu. 


\section{INFORMATION TO USERS}

This manuscript has been reproduced from the microfilm master. UMI films the text directly from the original or copy submitted. Thus, some thesis and dissertation copies are in typewriter face, while others may be from any type of computer printer.

The quality of this reproduction is dependent upon the quality of the copy submitted. Broken or indistinct print, colored or poor quality illustrations and photographs, print bleedthrough, substandard margins, and improper alignment can adversely affect reproduction.

In the unlikely event that the author did not send UMI a complete manuscript and there are missing pages, these will be noted. Also, if unauthorized copyright material had to be removed, a note will indicate the deletion.

Oversize materials (e.g., maps, drawings, charts) are reproduced by sectioning the original, beginning at the upper left-hand comer and continuing from left to right in equal sections with small overlaps. Each original is also photographed in one exposure and is included in reduced form at the back of the book.

Photographs included in the original manuscript have been reproduced xerographically in this copy. Higher quality $6^{n} \times 9^{n}$ black and white photographic prints are available for any photographs or illustrations appearing in this copy for an additional charge. Contact UMI directly to order.

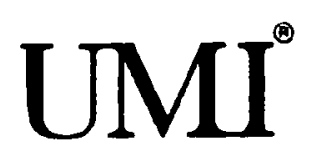

Bell \& Howell Information and Leaming 300 North Zeeb Road, Ann Arbor, MI 48106-1346 USA 800-521-0600 
Genetic Differences Between Two Growth-Forms of

LITHOPHYLLUM MARGARITAE.

\author{
A Thesis \\ Presented To \\ The Faculty of Moss Landing Marine Laboratories
}

In Partial Fulfillment

of the Requirements for the Degree

Masters of Science

in

Marine Sciences

By:

Timothy Nicholas Schaeffer

August 1999 
UMI Number: 1396197

\section{UMI Microform 1396197}

Copyright 1999, by UMI Company. All rights reserved.

This microform edition is protected against unauthorized copying under Title 17, United States Code.

\section{UMI \\ 300 North Zeeb Road \\ Ann Arbor, MI 48103}


(C)1999

Timothy Nicholas Schaeffer

ALL RIGHTS RESERVED 

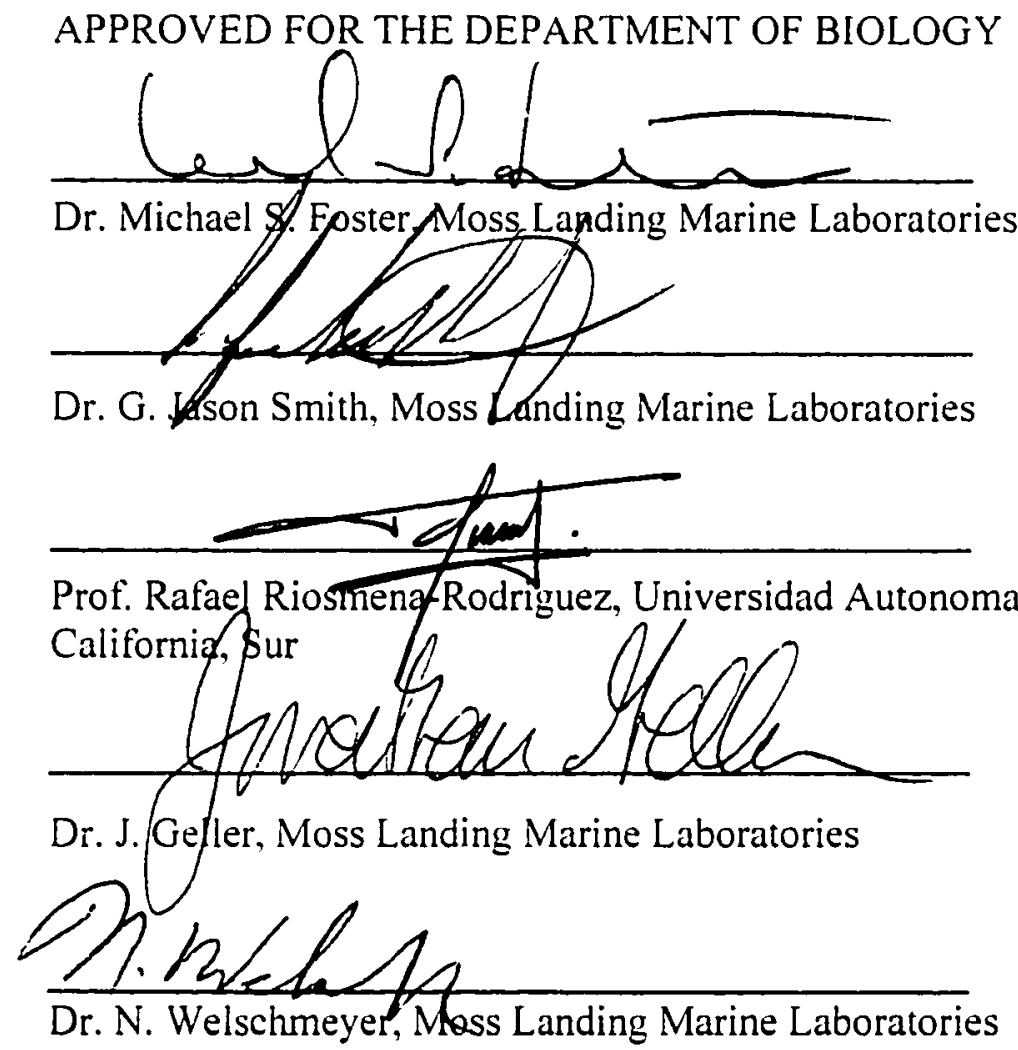

APPROVED FOR THE UNIVERSITY

William Fish 


\begin{abstract}
GENETIC DIFFERENCES BETWEEN TWO MORPHOLOGIES OF LITHOPHYLLUM MARGARITAE IN BAIA CALIFORNIA SUR.
\end{abstract}

By

Timothy Nicholas Schaeffer

Unattached, non-geniculate coralline algae or rhodoliths exhibit a range of morphological variability seemingly dependent on environmental factors. Rhodoliths have an extensive fossil record and may have environmentally dependent characteristics. making them potentially reliable paleoindicators. The rhodolith forming genus Lithophyllum spp. found in Baja California Sur. Mexico was recently consolidated. Under the new classification, $\underline{L}$. margaritae consists of several growth forms presumably reflecting local environmental conditions. In this study the genetic structure of several populations of this species from Baja California Sur, Mexico were examined using Amplified Fragment Length Polymorphisms (AFLP) with the goal of characterizing the extent of genetic variation associated with the foliose and fruticose morphologies described for this species. The data indicate these morphologies are genetically distinct. These results suggest exchange of genetic information between foliose and fruticose morpholgies of $\underline{L}$. margaritae is limited and that environmental conditions are not the only influence on growth forms of $\underline{L}$. margaritae. 


\section{Acknowledgments}

I want to express my appreciation to Moss Landing Marine Laboratories for providing an enriching and challenging educational experience. I thank my academic advisor, Dr. Mike Foster for his critical, constructive and encouraging support. I am grateful for the advice of my thesis committee, this includes Dr. Mike Foster, Dr. Jason Smith. Rafael Riosmena-Rodriguez, Dr. J. Geller, and Dr. N. Welschmeyer. I am especially thankful to Dr. Jason Smith and Dr. Tony DeTomaso for their generous contributions. I am grateful for the help from students of the phycology lab at Universidad Autonoma de Baja California Sur. I thank the Packard Foundation and the Dr. Earl and Ethyl Myers Trust for providing support for this study. Rhodoliths were collected in collaboration with Rafael Riosmena-Rodriguez at the Universidad Autonoma de Baja California Sur and support from an I.A.I. and CONABIO grant. I am particularly obliged from the help of Korie Johnson. Dave James, and Kate Stanbury. Lastly. I am always thankful of my family and friends for their unending support. 
TABLE OF CONTENTS

Pages

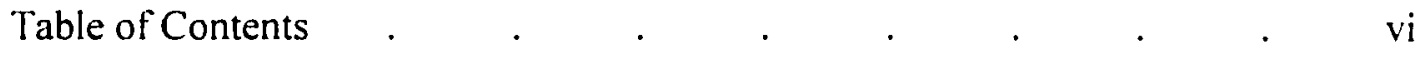

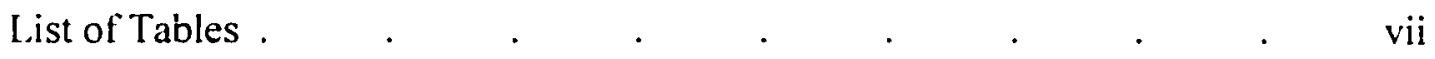

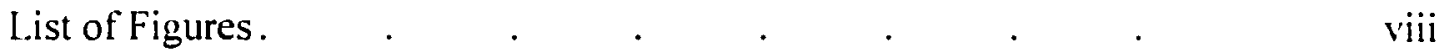

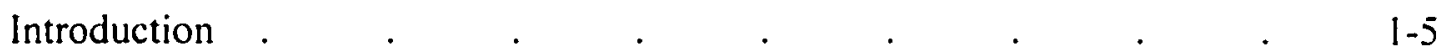

Materials and Methods . . . . . . . . . . $\quad$. $6-14$

Results. . . . . . . . . . . . $15-17$

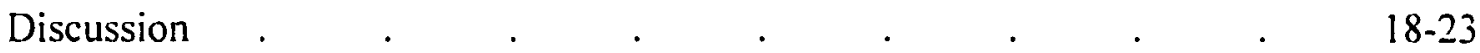

Literature Cited $\quad . \quad$. $\quad . \quad$. $\quad . \quad$. $\quad . \quad$. $\quad$ 24-30

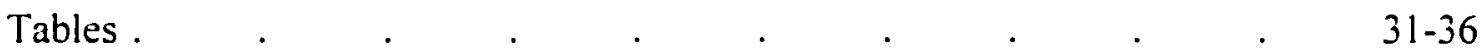

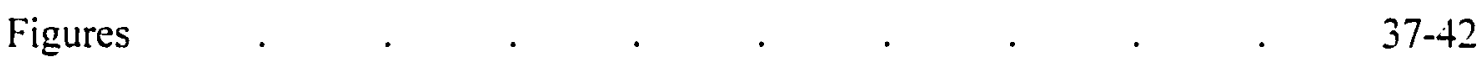




\section{LIST OF TABLES}

table

1. Sequences of primers and adaptors used for AFLP analyses.

2. Quantity of samples collected, ran and used in statistical analyses.

3. Similarity values (S) of individuals within populations prior to pooling data.

4. Matrix of similarity values (S) for within and among population. 34

5. $\quad F^{*}$-test results for among population comparisons. 


\section{LIST OF FIGURES}

figure

page

1. Map of locations sampled. 37

2. Growth forms sampled. 38

3. AFLP flowchart. $\quad 39$

4A. Total genomic DNA using guanidine thiocyanate. 40

4B. Total genomic DNA using protease. $\quad 40$

5. AFLP banding profile. 41

6. UPGMA tree. 42 


\section{INTRODUCTION}

Recent attention has been given to reconstructing past environmental conditions to better understand global change. The fossil record has been utilized as a source of indicators providing a record of ancient environments (Markwick. 1998; Pirrie. Marshall. and Crame. 1998: Ketcher and Allmon, 1993; Walker and Yamada, 1993). Critical to the reconstruction process for some organisms is assessing environmental dependence of morphological characteristics of extant representatives and fossil species. Uncertainty in this approach stems from a lack of knowledge regarding the genetic basis of morphological variation within a species compared to environmental influences. At one time. it had been proposed that in any organism "the demands of the environment may call forth any type of vegetative growth" (Wood-Jones, 1910, pg. 520). Later research. however, suggests the environment may not be the primary cause of morphological variability within some species (Chapman. 1974; Stearn, 1982; Espinoza and Chapman. 1983: Willis and Ayre, 1985). Stearn (1982) noted that most research testing environmental effects on the coral Acropora could not be understood exclusively on the basis of mechanical restraints. Willis and Ayre (1985) grant that environmental gradients modify coral morphology but found a high correlation between genotype and growthform. and suggested that major divisions in colony morphology are genetically determined. Such observations require that environmentally induced morphological variability be partitioned from heritable morphology in order to estimate ancient environmental conditions from living organisms. To test if morphology is 
environmentally induced, genetic analyses can be used to detect differences or similarities among morphologies of a species.

Organisms with calcium carbonate skeletons may be exceptional reef builders and can be well preserved in sediments. In some reef-building organisms. environmental factors are thought to promote the expression of a particular phenotype making them ideal paleoindicators. An example of such organisms are rhodoliths, free-living nongeniculate coralline algae (Corallinales, Rhodophyta). found in tropical. temperate, and arctic waters (Adey and MacIntyre. 1973: Johansen, 1981) at depths over $200 \mathrm{~m}$ to the intertidal zone (Littler, Littler. and Hanisak. 1991). New rhodoliths can arise in nonmuddy environments when crustose or branching corallines settle on unattached substrates or are detached from existing hard substrates (Bosence. 1983). and can be maintained by sexual and asexual reproduction. Rhodoliths are thought to grow slowly: deep water laminar forms. 20 to $30 \mathrm{~cm}$ diameter, could be 500-800 years old (Adey and MacIntyre. 1973). Currently, rhodoliths are placed in the Phylum Rhodophyta. Order Corallinales. Common names include Lithothamnion balls, algal balls, algally coatedgrains, rhodolites, algal nodules, maerl and chicharrones (Foster et al.. 1997).

The effects of environmental variables, such as water motion. light availability. and temperature on rhodolith morphology have been discussed extensively (Foslie, 1894; Lemoine 1910; Bosellini and Ginsburg, 1971; Adey and MacIntyre, 1973; Bosence. 1976; Bosence, 1983; Steneck, 1986; Braga \& Martin, 1988; Steller and Foster. 1995; Foster et al., 1997). Rhodolith morphologies in Bermuda Bay contained a consistent record of wave-induced rhodolith movement (Bosellini and Ginsburg, 1971). Bosence 
(1983) also noted that hydraulic energy influences crustose and branching growth-forms and is actually required for rhodolith survival. Braga and Martin (1988) state that for fossil material "the type of algae and their growth-forms seem to be controlled by the characteristics of the environment in which they developed" (pg. 300). Foster et al. (1997) reported two types of rhodolith beds in Baja California. Mexico, one type is characterized by gentle slopes with moderate wave action. called wave beds. and the other type is found relatively deeper and influenced by tidal currents. called current beds. They found that particular branching characteristics (e.g. sphericity. branch shape. branch density) of rhodoliths varied according to water motion within wave beds. Additionally, in rhodolith beds in Baja California Sur, Mexico, fruticose growth-forms are relatively high in abundance in both types of beds while foliose growth forms are restricted to deeper water (Yabur-Pacheco. 1998).

Demonstrating statistically insignificant genetic variability between rhodolith morphologies of the same species would support the use of rhodolith morphology as a reliable paleoenvironmental indicator. Additionally, the extent of genetic variation within and among populations could reflect the predominant mode of reproduction and potentially the magnitude of recruitment into and out of populations. Available evidence suggests rhodoliths may have relatively low gene flow within and between populations. Clonal propagation, through mechanisms such as fragmentation. minimizes genetic variability in populations because genetic information among individuals is not subject to the randomizing effect of independent assortment. Toomey (1975) found rhodoliths from the western Gulf of Mexico commonly had no "alien" nucleus, rather a nucleus initiated 
by a skeletal fragment suggesting individuals may grow from fragments. Proliferation through vegetative fragmentation has been noted by other researchers as well (Adey and MacIntyre. 1973; Bosence, 1976; Steller and Foster. 1995). Steller and Foster (1995) observed abundant pigmented fragments within beds and the absence of non-calcareous cores in larger rhodoliths. If propagation in rhodolith beds is primarily by fragmentation. then it is likely these populations should exhibit low genetic diversity. Depending on migration rates and clonal longevity, evidence for such clonal structure would highlight the importance of environmental control on phenotype in genetically similar individuals.

Genetic comparisons between morphologies both within and among populations could reveal associations between genetic and morphological characteristics. the degree of asexual reproduction, and the magnitude of genetic exchange between rhodolith populations. Alberte et al. (1994) pursued similar questions in their study of genetic similarity among and within populations of the seagrass Zostera marina. They found less genetic similarity between populations than within populations. suggesting interpopulation dispersal or recruitment from outside sources is limited relative to within population dispersal and recruitment. In other instances disjunct populations may not be

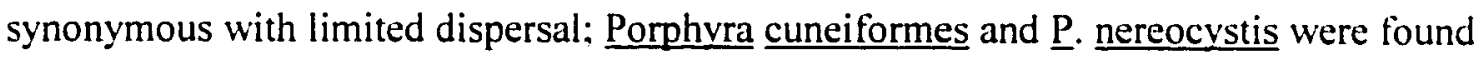
to have no within species variation even over a span of $1000 \mathrm{~km}$ (Lindstrom. 1993). Sosa and Garcia-Reina (1992) also found no correlation between genetic differences and geographical distance in Gelidium arbuscula. They did, however, found significant genetic variability between gametophytes and sporophytes indicative of asexual 
reproduction. The magnitude of genetic diversity within and among populations of rhodoliths is unknown but could be investigated with similar methods.

In this study. genetic variability was examined using Amplified Fragment Length Polymorphism (AFLP) techniques. AFLP is a relatively new method of PCR-based DNA fingerprinting. developed by Vos et al. (1995). AFLP is based on selective PCR amplifications of restriction fragments with the ability to detect single base pair differences between individuals. The technique produces individual as well population specific markers providing a spectrum of resolution. Genetic variability in the rhodolith forming alga Lithophyllum margaritae was examined relative to morphology and geographic distance. Lithophyllum margaritae is an ideal choice for several reasons. First. L. margaritae consists of several morphologies. all believed to be environmentally influenced. Second, the species has been reclassified by Riosmena-Rodriguez (1997) based on several microscopic features (esp. conceptacle morphology) as developed by Woelkerling (1988). As a result, three of the five Lithophyllum species found by Dawson (1960) in the Gulf of California were lumped into one species, Lithophyllum margaritae. Genetic fingerprinting techniques described in the work presented here can provide independent molecular evidence for this reclassification. Lastly. $\underline{\underline{L}}$. margaritae is found along a wide geographical gradient $(>500 \mathrm{~km})$ and well suited for among population comparison.

The null hypothesis that there is no significant difference in AFLP fingerprints between foliose and fruticose individuals of Lithophyllum margaritae within and among populations was tested. The objective of these analyses is to clarify the extent to which 
some rhodoliths can provide us with information from the past. and to what extent these organisms are exchanging genetic information. Bosence (1983) states "The realization that living rhodoliths may be hundreds to tens of thousands years old means that a relatively long term record of the sea floor conditions is preserved...they have been shown to preserve information on depth. geography, temperature and prevailing hydraulic energy" (pg. 218). The question is. does genetic variation affect the interpretation of this information? 


\section{MATERIALS \& METHODS}

\section{Collection}

Individual rhodoliths of the species Lithophyllum margaritae were collected from four populations in Baja California Sur, Mexico during 1998 (Fig. 1). A population of rhodoliths was defined as any contiguous bed of rhodoliths separated from another bed by at least $1 \mathrm{~km}$. Rhodoliths were collected in the La Paz region on January 23, 1998 from two populations. Manto de Diana $\left(24^{\circ} 50^{\prime} 47^{\prime \prime} \mathrm{N}, 110^{\circ} 36^{\prime} 26^{\prime \prime} \mathrm{W}\right)$. referred to as LP1. at $20 \mathrm{~m}$ depth and Manto de Pepe (24.52' $\left.01^{\prime \prime} \mathrm{N}, 110^{\circ} 33^{\prime} 54^{\prime \prime} \mathrm{W}\right)$, referred to as LP-2, at $12 \mathrm{~m}$ depth. Two populations in the Mulege region were sampled on March 20, 1998. Manto de James $\left(27^{\circ} 02^{\prime} 42.54^{\prime \prime} \mathrm{N}, 111^{\circ} 55^{\prime} .59 .28^{\prime \prime} \mathrm{W}\right)$, referred to as PC-1, at a depth of 8 $\mathrm{m}$ and Manto de Zachary $\left(27^{\circ} 03^{\prime} 6.6^{\prime \prime} \mathrm{N}, 111^{\circ} 57^{\prime} 56.94^{\prime \prime} \mathrm{W}\right)$, referred to as PC-2. at $10 \mathrm{~m}$. Rhodoliths of the fruticose (Fr) and foliose (Fo) growth-forms (Fig. 2) defined by Woelkerling et al. (1993) were collected haphazardly along the length of each bed and sealed in ZipLoc bags underwater. Immediately after collection, the bags containing rhodoliths were punctured several times, marked with place and time collected and transferred to a cooler with seawater. The cooler was equipped with a battery powered air pump to aerate and mix the water in an effort to facilitate rhodolith survival during transportation back to the laboratory. That samples collected were L. margaritae was 
confirmed by R. Riosmena-Rodriguez using taxonomic characteristics described by R. Riosmena-Rodriguez (1997).

\section{DNA Extraction}

Two methods were employed to recover high molecular weight DNA from living rhodoliths; one using guanidine thiocyanate extraction buffer and the second a protease (Qiagen Cat\#19155) based extraction. Both extraction methods require the rhodolith fragments to be ground in liquid $\mathrm{N}_{2}$. For guanidine thiocyanate extraction. 1-3 grams of rhodolith fragments were added to $15 \mathrm{~mL}$ of buffer (4M guanidine thiocyanate. $25 \mathrm{mM}$ sodium citrate. $\mathrm{pH} 7,0.5 \%(\mathrm{v} / \mathrm{v})$ sarcosyl and $0.7 \%$ of 2 -mercaptoethanol (added fresh)). This solution was heated at $65^{\circ} \mathrm{C}$ for $45-60$ minutes. The buffer solution was then centrifuged at $3000 \mathrm{xg}$ for 10 minutes and transferred to a new $50 \mathrm{~mL}$ tube, leaving ground plant debris in the initial tube. DNA was then extracted by adding an equal volume of phenol and chloroform (1:1 ratio). The solution was mixed by inverting the tubes gently several times and their organic and aqueous phase separated by centrifuging at $3000 \mathrm{xg}$ for 10 minutes. The lower organic phase was removed and an equal volume of chloroform and isoamyl (24:1 ratio) was added to the remaining aqueous phase. Again, samples were mixed by gentle inversion and spun at $3000 \mathrm{xg}$ for 10 minutes. These steps were repeated until particulate matter was no longer visible at the interface separating the aqueous and organic phase. The upper aqueous phase was then removed and transferred to a new $50 \mathrm{~mL}$ tube. Total nucleic acids were precipitated by the 
addition of $2 / 3$ volume of $100 \%$ isopropanol and stored at $-20^{\circ} \mathrm{C}$ for up to 2 weeks until DNA isolation.

For protease extractions, ground tissue was placed in a $50 \mathrm{~mL}$ tube with $10 \mathrm{~mL}$ of extraction buffer (50 mM Tris-HCl. pH 7.4, $10 \mathrm{mM}$ EDTA, $150 \mathrm{mM} \mathrm{NaCl} .2 .0 \%$ Sarcosyl. 0.5\% PVPP, freshly added 2.0\% 2-Mercaptoethanol and $0.4 \mathrm{mg} / \mathrm{mL}$ Qiagen Protease). Samples were incubated at $65^{\circ} \mathrm{C}$ for 30 minutes occasionally inverting. followed by a $37^{\circ} \mathrm{C}$ incubation and agitation at ca. $30 \mathrm{RPM}$ for 2 hours. The solution was then transferred to a new $50 \mathrm{~mL}$ tube and subjected to phenol and chloroform extractions. as described above. in order to remove proteins and other lipophilic components.

Preliminary results demonstrated guanidine thiocyanate extraction methods resulted in moderate yields of intact, high molecular weight DNA $(\geq 20 \mathrm{~kb})$ while protease extraction methods resulted in high yields but relatively degraded DNA $(\geq 10$ kb) and RNA. Although guanidine thiocyanate consistently resulted in high molecular weight DNA ( $\geq 20 \mathrm{~kb})$. this method required relatively large amounts of tissue ( $>2 \mathrm{~g})$. The protease based method. on the other hand. provided ample quantities of DNA with less tissue. Choice of extraction method for a given rhodolith depended on individual wet weight.

\section{DNA Isolation}

After precipitation with isopropanol, all samples were centrifuged at $3000 \mathrm{xg}$ for 20 minutes, pellets were washed with $70 \%$ ethanol and air dried. Once dry. pellets were 
dissolved in $2 \mathrm{~mL}$ of TE (10 mM Tris, pH 8, 10mM EDTA) and incubated overnight at room temperature. Pellets were completely dissolved in $\mathrm{TE}$ and $2 \mathrm{~g}$ of $\mathrm{CsCl}$ was added to each sample. Samples were then transferred to Beckman $3.9 \mathrm{~mL}$ polyallomer quick seal tubes containing $45 \mu \mathrm{L}$ ethidium bromide $(1 \mathrm{mg} / \mathrm{ml})$ and 1 drop (ca. $10 \mu \mathrm{L}$ ) of Triton-X100 (Sigma \#T9284). The tube was filled to the crown with $\mathrm{CsCl} / \mathrm{TE}(50 \mathrm{~g} \mathrm{CsCl}+50$ $\mathrm{mL} \mathrm{TE}$ ) and heat sealed. Samples were then spun at $100,000 \times \mathrm{xg}$ for 4 hours at $20^{\circ} \mathrm{C}$. After centrifugation. tubes were viewed in front of a UV light source in order to localize the high molecular weight DNA band. To isolate the DNA. bands were removed using a $1 \mathrm{~mL}$ syringe with an 18 guage needle. The $\mathrm{Cs} / \mathrm{Cl}$ solution containing rhodolith $\mathrm{DNA}$ was transferred to $1.5 \mathrm{~mL}$ centrifuge tubes and washed with salt saturated isopropanol $(50 \%(\mathrm{v} / \mathrm{v}) 5 \mathrm{M} \mathrm{NaCl}, 50 \%(\mathrm{v} / \mathrm{v})$ isopropanol) in order to remove ethidium from the DNA. Samples were gently inverted and centrifuged at $15.000 \mathrm{xg}$ for 3 minutes. This was repeated until samples no longer appeared pink (ca. 3 washes). The extracted DNA solutions were transferred to $15 \mathrm{~mL}$ snap cap tubes (Falcon $\# 2059$ ), then diluted with 2 volumes of TE ( $10 \mathrm{mM}$ Tris. pH 8.0. 10mM EDTA). $\mathrm{NaCl}$ was added to a final concentration of $0.2 \mathrm{M}$ from a $5 \mathrm{M}$ stock and 2 volumes of $-20^{\circ} \mathrm{C} 100 \%$ ethanol were added to each sample to precipitate the DNA. Samples were then incubated overnight at room temperature.

After overnight incubation, samples were centrifuged at $9000 \mathrm{xg}$ for 30 minutes and decanted. The remaining pellets were washed once with $70 \%$ ethanol, air dried and resuspended in $200 \mu \mathrm{L}$ TE for $1-2$ hours. Next, samples were transferred to $1.5 \mathrm{~mL}$ tubes and mixed with $100 \mu \mathrm{L} 7.5 \mathrm{M} \mathrm{NH}_{40} \mathrm{Ac}$ and $600 \mu \mathrm{L}$ ethanol, incubated for I hour at room 
temperature, centrifuged at $15,000 \mathrm{xg}$ for 15 minutes, and washed with $70 \%$ ethanol.

Remaining pellets were then air dried and resuspended in $50 \mu \mathrm{L}$ of TE overnight at $4^{\circ} \mathrm{C}$.

Yield of DNA was quantified from each sample by using UV spectrophotometry. DNA samples were diluted in $\mathrm{dH}_{2} \mathrm{O}$ and absorbances determined at 260 and $350 \mathrm{~nm}$ for

$$
\text { Eq. } 1 \quad\left[\left(\mathrm{OD}_{260}-\mathrm{OD}_{350}\right) 50\right] / 10=\mathrm{X} \mu \mathrm{g} \cdot \mu \mathrm{L}^{-1}
$$

use in Eq.1 yielding DNA concentration in $\mu \mathrm{g} \cdot \mu \mathrm{L}^{-1}$. Once quantified. DNA samples were checked for integrity by adding $5 \mu \mathrm{L}$ of sample to $1 \mu \mathrm{L}$ of sample buffer $(.025 \%$ bromophenol blue (v/v), 0.25\% xylene cyanol FF (v/v), 1.5\% Ficoll (w/v). 10\% 10X TE. $\left.80 \% \mathrm{H}_{2} \mathrm{O}\right)$ and run on a $0.7 \%$ agarose gel $(30 \mathrm{~mL} 1$ X TAE $(0.04 \mathrm{M}$ Tris. $0.1 \%$ glacial acetic acid. .001 M EDTA. pH 8.0), $210 \mathrm{mg}$ agarose (BioRad Molecular Biology Grade). $1.5 \mu \mathrm{L} 1 \mathrm{mg} / \mathrm{mL}$ ethidium bromide) for 40 minutes at $50 \mathrm{~V}$.

\section{Size Selection of Genomic DNA}

A compromise between DNA yield and quantity was encountered with the different extraction protocols. $\mathrm{CsCl}$ banded DNA samples were subjected to agarose gel purification to standardize the size range of DNA fragments subjected to AFLP analysis. DNA samples were separated on $0.7 \%$ agarose, IX TAE gels as previously described. Samples of genomic DNA of $20-25 \mathrm{~kb}$ in size, based on migration relative to $\lambda$ DNA digested with Hind III, were excised from the gel and placed in $1.5 \mathrm{~mL}$ centrifuge tubes. To each tube, $900 \mu \mathrm{L}$ of lysis buffer ( $10 \mathrm{M}$ guanidine thiocyanate, $0.1 \mathrm{M}$ Tris- $\mathrm{HCl}, \mathrm{pH}$ 6.4, 0.2 M EDTA. pH 8.0 and Triton X-100) and $40 \mu \mathrm{L}$ of glass milk (Bio $101 \# 1001$ - 
604) was added. Samples were then vortexed and incubated at room temperature for 10 minutes. To keep the glass milk in suspension, samples were vortexed for approximately 5 seconds at 2 minute intervals during incubation. Samples were then centrifuged at $12.000 \mathrm{xg}$ for $7 \mathrm{sec}$. and the supernatant was removed. Pellets were then washed once with wash buffer (10 M guanidine thiocyanate, $0.1 \mathrm{M}$ Tris-HCl, $\mathrm{pH}$ 6.4), vortexed. centrifuged again at $12.000 \times \mathrm{xg}$ for 7 seconds and the supernatant discarded. Samples were then washed twice with $70 \%$ ethanol. once with $100 \%$ acetone, vortexed and centrifuged with the supernatant removed between every wash. After the supernatant was removed following the last wash. samples were kept at $56^{\circ} \mathrm{C}$ with the lids open to evaporate residual acetone. Thirty-five $\mu \mathrm{L}$ of water was then added to each sample. and samples were vortexed and placed at $56^{\circ} \mathrm{C}$ for ten minutes. After incubation samples were centrifuged at $12.000 \mathrm{xg}$ for 2 minutes and the supernatant was pipetted to new 0.6 $\mathrm{mL}$ centrifuge tubes. To dissolve any residual DNA, another $35 \mu \mathrm{L}$ of water was added again to the original pellet. and the sample was incubated at $56^{\circ} \mathrm{C}$ for ten minutes. After incubation, samples were spun at $12.000 \mathrm{xg}$ for 2 minutes and the supernatant was added to the original supernatant corresponding to each sample. The $0.6 \mathrm{~mL}$ centrifuge tubes were then spun for $5 \mathrm{~min}$. at $12,000 \mathrm{xg}$ to concentrate any leftover glass milk. Samples were then transferred to a new $0.6 \mathrm{~mL}$ centrifuge tube. 


\section{Amplified Fragment Length Polymorphisms}

Amplified fragment length polymorphism (AFLP) methods, introduced by Vos et al. (1995), followed modifications by De Tomaso et al. (1998). The general protocol is depicted in figure 3. DNA (200 ng) was reduced in size by restriction enzyme digestion with 5 units EcoR I and 5 units MseI (New England BioLabs) for 2 hours at $37^{\circ} \mathrm{C}$ in a 30 $\mu \mathrm{L}$ reaction volume using the recommended buffer (New England Biolabs Buffer 2). Oligonucleotide adaptors (5 pMol - EcoR I. $50 \mathrm{pMol}$ - Mse I) compatible with EcoR I and Mse I (Table 1) cohesive ends were ligated onto the rhodolith DNA fragments using 15 units of T4 ligase (Promega) in a total volume of $40 \mu \mathrm{L}$. Ligation reactions were incubated for 3-12 hours. After the ligation reaction. $60 \mu \mathrm{L}$ of TE ( $10 \mathrm{mM}$ Tris. pH 8.0. $10 \mathrm{mM}$ EDTA) was added to each sample. The diluted adaptor ligated DNA $(4 \mu \mathrm{L})$ was subjected to PCR amplification (preamplification) with 30 ng of pre-selection oligonucleotide primers (Table 1) encompassing the restriction size sequence plus one base at the $3^{\circ}$ end. Buffer 2 (New England Biolabs) and 0.5 units Taq polymerase. The PCR reaction was carried out in a Model TCl Thermocycler (Perkin Elmer) in the following manner: 1 cycle of $72^{\circ} \mathrm{C}$ for $2 \mathrm{~min}$, followed by 20 cycles of $94^{\circ} \mathrm{C}(30$ seconds), $56^{\circ} \mathrm{C}$ ( 30 seconds), and $72^{\circ} \mathrm{C}(1$ minute). The preamplification reactions were diluted $\mathrm{i}: 20$ in TE and $3 \mu \mathrm{L}$ was used for AFLP fingerprinting with each primer containing 3 additional selective nucleotides. The EcoR I selective primer was labeled with ${ }^{33} \mathrm{P}-\gamma \mathrm{ATP}$ using a polynucleotide kinase under standard reaction conditions (DeTomaso et al., 1998). Reaction conditions for the selective amplification consisted of 
the following: initial $2 \mathrm{~min}$. hold at $95^{\circ} \mathrm{C}$ for template denaturation followed by 1 cycle of $94^{\circ} \mathrm{C}$ for $30 \mathrm{sec} ., 65^{\circ} \mathrm{C}$ for $30 \mathrm{sec}$. and $72^{\circ} \mathrm{C}$ for $1 \mathrm{~min}$. AFLP products specific for the selective primer combination were subsequently amplified during 24 cycles comprised of $94^{\circ} \mathrm{C}$ for $30 \mathrm{sec} ., 56^{\circ} \mathrm{C}$ for $30 \mathrm{sec}$. and $72^{\circ} \mathrm{C}$ for $1 \mathrm{~min}$. Following PCR reactions. samples were incubated in an equal volume of stop solution $(98 \%$ formamide. $10 \mathrm{mM}$ EDTA pH 8.0. $0.1 \%$ bromophenol blue, $0.1 \%$ xylene cyanol) for $5 \mathrm{~min}$. at $95^{\circ} \mathrm{C}$. Samples were loaded onto $38 \times 50 \mathrm{~cm}$ denaturing acrylamide gels (42\% Urea w/v. 12\% $10 \mathrm{X}$ TBE v/v, $10 \%$ Long Ranger (50\%) v/v. .05\% TEMED and .05\% Ammonium Persulfate $\mathrm{v} / \mathrm{v}$ ) and run at 80 watts for approximately 2.5 hours using a SequiGen (BioRad) apparatus. Reference DNA was loaded the span of each gel to provide a check for gel induced curvature. Gels were transferred to paper, vacuum dried and placed under Kodak X-Omat film for approximately 36 hours.

\section{Data Analyses}

AFLP fingerprints for each sample were coded by the distance in centimeters traveled by each band. Data were entered in a spreadsheet and analyzed using SIM 1.01 (Zimmerman, 1993). SIM 1.01 calculates Similarity values (S), using Eq. 2 (Lynch,

$$
\text { Eq. } 2 \mathrm{~S}_{x y}=2 \mathrm{n}_{x y} /\left(\mathrm{n}_{x}+\mathrm{n}_{\mathrm{y}}\right)
$$

1990), where the $\mathrm{S}$ of two individuals, $x$ and $y$, is twice the number of common AFLP bands in their fingerprint profiles $\left(\mathrm{n}_{x y}\right)$ divided by the total number of bands exhibited in both individuals or as the fraction of shared bands. Average genetic similarity within and 
among populations is calculated by making all possible pairwise comparisons of $\mathrm{S}_{\mathrm{xy}}$ among individuals. SIM 1.01 calculates the covariance caused by recursive comparisons (Lynch, 1990; Danforth and Freeman-Gallant, 1996) with the same individuals and adds this component to the total variance of each statistical population. From the pairwise comparisons. SIM 1.01 uses the $F^{\prime}$ (Eq. 3) statistic (Wright, 1951) to test the null

$$
\text { Eq. } 3 F^{\prime}=D_{h} /\left(D_{w}+D_{h}\right)
$$

hypothesis that $F^{\prime}=0$. In Eq. 3, $D_{b}$ is the average dissimilarity $(D=1-S)$ between populations $i$ and $j$ and $\mathrm{D}_{\mathrm{w}}$ is the average dissimilarity within population $i$. Foliose and fruticose samples from populations within geographic regions were treated as separate populations in statistical analyses to test the null hypothesis that similarity values are equal among morphologies within a population. Rejection of this null hypothesis would demonstrate a genetic difference between morphologies.

Statistical assumptions of an F-test were tested using $F_{\max }$ and KolmogorovSmirnoff tests to verify the homoscedasticity of the error terms and that the data are distributed normally. To gain insight into the stratification of all populations. multiple comparisons were performed using SIM 1.01 to determine if a given morphology had a significantly different banding pattern between adjacent populations and between regions. If significant differences were not observed between adjacent populations then they were pooled. An alpha of 0.05 was determined a priori as the experimentwise error rate. To avoid a Type I error during the comparisons, the Dunn-Sidak method for multiple significance tests was used (Sokal and Rohlf, 1995). This method adjusts alpha for each comparison $\left(\alpha^{\prime}=1-(1-\alpha)^{1 / k}\right.$ where $k$ is the $k^{\text {th }}$ comparison). 
To visualize genetic structure within and among the $\underline{L}$. margaritae populations sampled, an unweighted pair group method with arithmetic averages (UPGMA) analysis was performed using the software package TFPGA v1.3 (Miller. 1997). This analysis is adapted to AFLPs by assuming the presence of a particular band represents one allele and the absence of the same band in another individual represents another allele. The analysis results in a graphical tree consisting of branches representing genetic distances (D) between statistical populations and bootstrap values indicating the degree of confidence for each node. Genetic distances are calculated using the equation provided by Nei (1978). 


\section{$\underline{\text { RESULTS }}$}

The two DNA extraction techniques employed resulted in different yields and integrity of DNA. DNA from foliose samples produced a mean of $5.8 \mu \mathrm{g} \mathrm{DNA} / \mathrm{g}$ wet tissue $(+/-5.1)$ when extracted with the protease and $1.5 \mu \mathrm{g} \mathrm{DNA} / \mathrm{g}$ wet tissue $(+/-1.4)$ with guanidine thiocyanate. Fruticose samples yielded an average of $6.9 \mu \mathrm{g} \mathrm{DNA} / \mathrm{g}$ wet tissue $(+/-4.8)$ with the protease and $2.3 \mu \mathrm{g} \mathrm{DNA} / \mathrm{g}$ wet tissue $(+/-1.7)$ with guanidine thiocyanate. Samples extracted with the protease yielded significantly more $\mu \mathrm{g}$ DNA per gram of wet tissue than guanidine thiocyanate extractions for both fruticose $(p<0.05$. $t=4.4, d f=17)$ and foliose $(p<0.05, t=3.8, d f=20)$ rhodoliths. In addition to differences in yield, the two extraction protocols differed in the molecular size range of DNA fragments produced (Fig. 4A \& 4B). Guanidine thiocyanate extractions were characterized by the presence of a single band $(23 \mathrm{~kb})$ indicative that DNA remained intact while protease extractions were distinguished by higher yields but partially degraded ( $23 \mathrm{~kb}-1 \mathrm{~kb}$ range) DNA suggesting degradation.

Twenty-five samples of each morphology were collected from each population. Different primer combinations were attempted with the goal of obtaining more AFLP products for each sample. Bands from the F4 primer were not included in analyses because too many samples were unscorable, however. of the samples which were "clean". the patterns were similar to the E4 primer. After DNA extraction, AFLP processing, and using the E4 primer the number of unambiguous and usable samples within a morphology of a particular population ranged from 4-10 (Table 2). AFLP products 
ranged in size from 100-400 bp. Among all samples, ninety-nine different loci were scored. 32 of which were common to both morphologies. The remaining 67 loci were exclusive to a particular morphology. Two bands. approximately 150 and 290 bp. were found in nearly every sample and there were 3 bands (175. 195. and $200 \mathrm{bp}$ ) present in every foliose sample while there were no consistent bands in all fruticose samples. Fruticose samples on average yielded $14(+/-4.0 \mathrm{SD})$ bands while foliose samples generally had $22.8(+/-3.0 \mathrm{SD})$ bands (Fig. 5).

Results from comparisons of like growth-forms between adjacent populations within a region suggest samples were not collected from genetically distinct populations. Similarity values of foliose populations ranged from $0.75-0.85$ and fruticose populations from $0.55-0.67$ (Table 3). Fruticose samples collected from the 2 populations in La Paz were not significantly different $(p>0.05)$ nor were foliose samples $(p>0.05)$. The same set of comparisons were performed on foliose and fruticose samples in Pta. Chivato. There was no significant difference $(p<0.05)$ between fruticose samples from the two Pta. Chivato populations but there was significant difference between foliose samples $(p<0.01) . F_{\max }$ tests performed on the data revealed heteroscedastic variances $\left(F_{\max .01[8.9]}\right.$ $\left.=49, F_{\text {crit }}=13.9\right)$. Kolmogorov-Smirnoff tests concluded that ciata within all populations were normally distributed. Because of the low sample size from each population, the heteroscedastic data and the results of the multiple comparisons (despite not meeting the assumptions of the $F$ test). populations of morphologies within each region were pooled. For example, LP1A and LP2A, both in the La Paz region. were pooled into one La Paz population (LP). Pooling the data increased the sample size of each group and produced 
homoscedastic data $\left(F_{\text {max.01[4. 27] }}=2.77, F_{\text {cril }}=3.3\right)$. Similarity values for within pooled populations ranged from $0.83(+/-0.1 \mathrm{SD})$ to $0.76(+/-0.2 \mathrm{SD})$ for foliose and $0.61(+/-0.1$ SD) to 0.57 (+/-0.2 SD) for fruticose. Similarity values between populations, including between morphology comparisons, ranged from $0.76(+/-0.1)$ to $0.38(+/-0.1)$. All $\mathrm{S}$ values from pooled populations can be found in Table 4. Analyses performed in the pooled populations resulted in a significant differences in genetic similarity between all populations (Table 5).

The UPGMA analysis produced a dendrogram that grouped populations primarily by growth-form and secondly by geography (Fig. 6). After 1000 permutations the analysis resulted in 7 nodes and the associated proportion of similar replicates relative to the number of permutations. Node 1 included the $2 \mathrm{La} \mathrm{Paz}$ fruticose populations with a distance (D) of 0.016 ( $83 \%$ proportion of similar replicates). Node 2 included the $2 \mathrm{La}$ Paz fruticose populations and a Pta. Chivato fruticose population ( $D=0.03 .83 \%$ proportion of similar replicates). Node 3 contained of all fruticose populations $(D=0.055$. $74 \%$ proportion of similar replicates). Node 4 consisted of the 2 La Paz Foliose populations ( $D=0.019 .78 \%$ proportion of similar replicates), and Node 5 the two Pta. Chivato foliose populations $(\mathrm{D}=0.037,53 \%$ proportion of similar replicates). Node 6 included all foliose populations ( $D=0.058,62 \%$ proportion of similar replicates) . Lastly. node 7 included all populations ( $D=0.087,100 \%$ proportion of similar replicates). 


\section{DISCUSSION}

Demonstrating a genetic trend correlated with morphological variability has long been "a central theme in phycology" (Bhattacharya and Druehl, 1989). This study represents the first application of AFLP analyses in marine algae and may be the only paper to examine morpho-genetic relationships in the corallines. While there is limited genetic data for corallines, studies utilizing different genetic techniques in other species of algae are available for comparisons. Sideman and Mathieson (1985) were able to correlate genetic trends among morphotypes of Fucus distichus associated with protected and exposed sites. John et al. (1993) used 18S rRNA genes to reveal morphotypes of the genus Microthamnion. previously believed to be genetically different. were indistinguishable. Using a combination of allozyme and random amplified polymorphic DNA (RAPD) analyses. Van Oppen. Oslen, and Stam (1995) were able to demonstrate a clear distinction between western and eastern North Atlantic species of Phvcodrvs rubens. Bhattacharya and Druehl (1989) attempted to delineate morphologically distinct populations of Costaria costata using DNA sequencing and RFLP analysis. One polymorphism was detected employing 42 RFLP probes. Based on the one polymorphism, they suggested morphological variability in Costaria costata is probably genetic. Relative to the results presented by Bhattacharya and Druehl (1989), the differences found in this study are relatively large. The present results were obtained using 1 primer set yielding ninety-nine polymorphisms each capable of detecting single base pair differences. 
Analyses using AFLPs are reproducible and detect a relatively high number of polymorphisms (Vos et al., 1995) in addition to being reliable and robust (Becker et al.. 1995). Due to the number of loci sampled (potentially screening the entire genome) in a single assay, polymorphisms revealed per reaction are much higher than by RFLPs or RAPDs (Paul et al.. 1997). AFLPs can provide a range of resolution- some bands are invariably retained among samples while some are individual specific. AFLPs have been used to assess genetic variability between and within populations and to estimate interand intraspecific genetic variation of species in both plants and animals (Janssen et al.. 1996: Majer et al.. 1996: Paul et al., 1997; DeTomaso et al.. 1998).

The data from this study illustrate a significant difference in AFLP band profiles between foliose and fruticose growth-forms of $\underline{L}$. margaritac. Foliose individuals from one population are more closely related to foliose individuals from populations $>250 \mathrm{~km}$ away than to fruticose individuals in the same population. These results indicate that there is severely limited or non-existent gene flow between the two growth-forms. The genetic distance based UPGMA results indicate that growth-form reflects a larger genetic component effect than geographic distribution when comparing between growth-form and among populations (Fig. 6). In this study, the genetic differences between growthforms are used to examine $\underline{L}$. margaritae as a species and as a paleoindicator.

A potential source of the observed genetic contrast between the foliose and fruticose growth-forms of $\underline{L}$. margaritae are differences in reproductive events. Mechanisms of reproduction in the coralline algae are poorly understood. even relative to the other red algae. Nearly nothing is known about spore viability, dispersal, or habitat 
selection in corallines (Steneck, 1986) except that coralline spores are negatively buoyant upon their release (Bold and Wynne, 1985). Edyvean and Ford (1986) estimated one species of Lithophyllum sp. had an estimated spore survival rate of $.000003119 \%$. Spore and rhodolith survival can also be affected by environmental conditions (Woelkerling. 1988). Because coralline spores, like other red algae, are not flagellated and their low survival rate, it seems gene flow could be affected by the ability of currents to quickly disperse spores.

Fragmentation in rhodolith beds is thought to be common (Adey and MacIntyre. 1973: Toomey, 1975; Bosence. 1976; Steller and Foster. 1995). Woelkerling (1988) reported that among some rhodolith populations examined, the "proportion of gametangial plants never exceeded $20.4 \%$ in any population" (pg. 187). furthermore. reproductive individuals in some populations of $\underline{L}$. margaritae in the Gulf are approximately $98 \%$ tetrasporophytic and spore availability can be low (Riosmena. pers. comm.). The absence or low proportion of gametangial individuals in rhodolith populations suggests there is some degree of asexual reproduction (i.e. fragmentation or bispores). In this study, however, no identical individuals were found among all samples of both growth-forms indicating that fragmentation is either unsuccessful, an uncommon event, or only uncommon in current beds. Lower survivorship of fragments could explain genetic diversity above what is expected in a population seemingly dependent on fragmentation for propagation. Although rates of successful asexual reproduction may be low overall, it seems to occur more frequently in foliose samples than fruticose based on their higher within population similarity values. 
Rhodoliths in the Gulf of California can be found in both shallow and deep water habitats characterized by wave or current motion, respectively (Foster et al.. 1997). Beds sampled in this study are in relatively deep water and are considered current driven beds. Generally, foliose individuals are restricted to relatively low hydrodynamic energy areas while fruticose individuals are found in a wide range of areas, including shallow habitats with relatively high hydrodynamic energy and deeper, relatively calmer habitats (YaburPacheco, 1998). The AFLP analysis of $\underline{L}$. margaritae indicate that similarity values within and among foliose populations are consistently higher than those observed for fruticose samples. It seems counter-intuitive that foliose individuals. generally restricted to deeper waters, are exchanging genetic information more effectively than a growthform found in a range of wave-energy habitats. The differences in similarity values among populations of the growth-forms could be explained as varied responses of spores to the environment. It seems unlikely, however, that growth-form alone could account for the differences in population gene flow. It could be that potential allelic combinations in foliose individuals are fewer than in fruticose individuals or that vegetative propagation is more successful in one of the growth-forms. Another alternative is that populations should be tested with more AFL.P primer sets. Different primer sequences could produce a range of among and within population similarity values; however. tests with the F4 primer revealed similar patterns between the two growth-forms.

Although the two growth-forms of $\underline{L}$. margaritae can vary in relative abundance. samples were collected in areas where growth-forms were found living on top of one another. It is unlikely mechanisms of allopatric speciation are a source of genetic 
differentiation. Another possible mechanism of divergence may be through reproductive isolation. For example, hybrids of the two growth-forms may be relatively inviable and consequently unable to propagate, failing to bridge the gap between growth-forms. Another potential source of reproductive isolation could be a difference in the timing of reproduction. which could limit interbreeding.

An alternative explanation of the genetic differences between foliose and fruticose growth-forms is that they represent different species although this is difficult to evaluate due to the experimental design of the present study. However. the validity of treating both growth-forms as $\underline{\mathrm{L}}$. margaritae is questionable because of their apparent reproductive isolation Relatively recently, Riosmena-Rodriguez (1997) re-examined the taxonomic status of the rhodolith forming genus Lithophyllum in the Gulf of California. Prior to Riosmena-Rodriguez (1997), rhodoliths in this region had last been examined by Dawson (1960) who reported two species of Lithothamnion and five species of Lithophvllum based on 9 morphological characters. Riosmena-Rodriguez (1997) applied rhodoliths reported as Lithophyllum by Dawson (1960) to the generic concept of Lithophyllum set forth by Woelkerling $(1983,1988)$ and Irvine and Chamberlain (1994). Riosmena-Rodriguez (1997) found that "all species recognized by Dawson (1960). and their synonyms, indicated that most material fit the generic concept of Lithophyllum..." (pg. 5). Riosmena-Rodriguez (1997) further reviewed populations of the same rhodoliths using traits provided by Woelkerling and Campbell (1992), Irvine and Chamberlain (1994), Chamberlain (1996) and Woelkerling (1996), to evaluate species. Of 81 characteristics provided by Woelkerling and Campbell (1992) 13 were not applicable and 
the remaining 68 could not be reliably used due to a wide range of variability or invariability. Consequently. 4 characteristics associated with conceptacle growth-form were used. The 4 characteristics used agreed invariably from population to population for Lithophvllum from the Gulf (Riosmena-Rodriguez, 1997). Despite these similarities. the genetic differences in this study are clear although the data are unclear as to whether they demarcate one species from another. A combination of genetic and taxonomic studies are necessary to determine if these differences are large enough to conclude that each growth-form represents a different species. Further molecular studies using markers more appropriate for higher phylogenetic resolution (eg. 18S rRNA) could test the relationships of thodolith forming species by applying the same molecular test to related but validated species and estimating relatedness using standard phylogenetic methods.

Steller and Foster (1995) point out that more taxonomic studies are needed in order to make judgements regarding plant size and branch density when considering environmental effects on growth-form. They further point out that "variability in branch density and plant size among beds suggests that rhodolith morphology may not simply be a function of water motion" (pg. 210). Adey and MacIntyre (1973) claim that simplification of "the taxonomic structure of corallines has threatened to add considerable confusion to modern marine studies" (pg. 884). They further warn that "without some knowledge of the genera and their environmental limitations" (pg. 884) paleoenvironments cannot be interpreted simply from the occurrence of crustose corallines. While Adey and MacIntyre (1973) recognize that species of rhodoliths can be influenced by some physical factors they suggest "care should been taken on generalizing 
this pattern until more information becomes available" (pg. 890). Reid and MacIntrye (1988) concluded that some morphological characteristics of rhodoliths in the eastern Caribbean have unreliable relationships with the environment. Thus using rhodoliths as paleoindicators may not be straightforward. The molecular data presented here suggest that more thought should be given to taxonomic uncertainties. It is clear that some morphological characteristics of rhodoliths such as shape and branch density are influenced by environmental factors (Bosellini and Ginsburg. 1971; Wray, 1971: Bosence, 1976; Steller and Foster, 1995; Foster et al., 1995). The results presented here. however, indicate a strong genetic component is also associated with the foliose vs. fruticose growth-forms of $\underline{\underline{L}}$. margaritae. While it is unknown what the loci sampled code for. the data suggest the loci sampled of the two growth-forms are significantly different from each other. Data on the full life history of $\underline{L}$. margaritae, in particular. and rhodoliths in general would help clarify dynamics of these populations. 


\section{LITERATURE CITED}

Adey, W.H. and MacIntyre, I.G. 1973. Crustose coralline algae: a re--evaluation in the geological sciences. Geol. Soc. Am. Bul. 84:883--904

Alberte. R.S.. Suba. G.K.. Procaccini. G.R., and Zimmerman. R.C. 1994. Assessment of genetic diversity of seagrass populations using DNA fingerprinting: Implications for population stability and management. Proc. Natl. Acad. Sci. USA. 91:10491053

Avise. J.C. 1994. Molecular Markers. Natural History and Evolution. Chapman and Hall. New York. New York. 511 pp.

Becker. J.. Vos. P., Kuiper. M.. Salamini, F., and Heun. M. 1995. Combined mapping of AFLP and RFLP markers in barley. Mol. Gen. Genet. 249:65-73

Bhattacharya. D. and Druehl. L.D.1989. Morphological variability and DNA sequence variation in the kelp Costaria costata (Phaeophyta). Mar. Biol. 102: 15-23

Bold. H.C. and M.J. Wynne. 1985. Introduction to the algae. 2nd ed. Prentice--Hall. Inc.. Englewood Cliffs, New Jersey. 720 pp.

Bosellini. A. and Ginsburg, R.N. 1971. Form and internal structure of recent algal nodules (rhodolites) from Bermuda. Journal of Geology. 79:669-682

Bosence. D.W.J. 1976. Ecological Studies on two unattached coralline algae from western Ireland. Paleontology. 19:365-395 
Bosence. D.W.J. 1983. Description and classification of rhodoliths (rhodoids. rhodolites). In Coated Grains (ed. by T.M. Peryt). Springer-Verlag. Berlin. 217224

Braga. J.C. and Martin. J.M. 1988. Neogene coralline--algal growth--forms and their palaeoenvironments in the Almanzora River Valley. Palaeoecology. 67: 285-303

Chamberlain. Y.M. 1996. Lithophylloid Corallinaceae (Rhodophyta of the genera Lithophyllum and Titanoderma from Southern Africa. Phycologia 35: 204-221

Chapman. A. 1974. The genetic basis of morphological differentiation in some Laminaria populations. Mar. Biol. 24: 85-91

Coyer. J.A.. Olsen, J.L., and Stam. W.T. 1997. Genetic variability and spatial separation in the sea palm Postelsia palmaeformis (Phaeophyceae) as assessed with M13 fingerprints and RAPDS. J. Phycol. 33:561-568

Danforth. B.N. and Freeman--Gallant, C.R. 1996. DNA fingerprinting data and the problem of non--independence among pairwise comparisons. Molecular Ecology. $5: 221-227$

Dawson, E.Y., 1960. Marine Red Algae of Pacific Mexico. Part 3. Cryptonemiales, Corallinaceae subfamily Melobesioideae. Pacific Naturalist. 2:3-125

De Tomaso. A.W., Saito. Y.. Ishikuza, K.J., Palmeri. K.J., and Weissman. I.L 1998. Mapping the genome of a model protochordate. I. A low resolution genetic map encompassing the fusion/histocompatibility $(\mathrm{Fu} / \mathrm{HC})$ locus of Botrvllus schlosseri. Genetics. 149:277-287 
Edvyean, R.G.J. and Ford. H. 1986. Spore production by Lithophyllum incrustans (Corallinales, Rhodophyta) from south west Wales. Field Stud. 6:397-405 pp.

Espinoza, J. and Chapman, A. 1983. Ecotypic differentiation of Laminaria longicrusis in relation to seawater nitrate concentration. Mar. Biol. 74:213-218

Foslie, M. 1894. New or critical Lithothamnia. Det Kongelige Norske Videnskabers Selskabs Skrifer. 1894 (2): 1-10

Foster. M.S., Riosmena--Rodriguez. R., Steller, D.L.. and Woelkerling. Wm. J. 1997. Living rhodolith beds in the Gulf of California and their implications for paleoenvironmental interpretations. In: Pliocene carbonates and related facies flanking the Gulf of California, Baja California Sur, Mexico. (Ed. By M.E. Johnson and J. Ledezma--Vazquez). Bulletin of the Geological Society of America. 318:127-140

Hariot, P. 1895. Algues du Golfe de California recuellies par M. Diguet. Journal of Botany. 9:167-170

Irvine. L.M.. and Chamberlain, Y.M. 1994. Seaweeds of the British Isles. Volume 1 Rhodophyta_Part 2B Corallinales. Hildenbrandiales. Natural History Museum, London. $276 \mathrm{pp}$.

Janssen. P., Coopman, R., Huys, G., Swings, J., Bleeker, M., Vos, P.. Zabeau, M.. and Kersters, K. 1996. Evaluation of the DNA fingerprinting method AFLP as a new tool in bacterial taxonomy. Microbiology 142: 1881-1893

Johansen, H.W. 1981. Coralline Algae, A First Synthesis. CRC Press, Boca Raton. Florida. 239pp. 
John. D.M., Bhoday, R.. Russel, S.J., Johnson, L.R. and Gacesa, P. 1993. A molecular and morphological analysis of Microthamnion (Chlorophyta, Microthamniales). Arch. Protistenkd. 143: 33-39

Kazan. K.. Manners. J.M., and Cameron, D.F. 1993. Genetic variation in agronomically important species of Stylosanthes determined using random amplified polymorphic DNA markers. Theor. Appl. Genet. 85:882-888

Ketcher. K. and Allmon. W. D. 1993. Environment and Mode of Deposition of a Pliocene Coral Bed: Coral Thickets and Storms in the Fossil Record. Palaios. $8(1): 3-17$

Lemoine. Mme. P. 1910. Structure anatomique des Melobesiees. Aplication a la clasification. Annuaire du Institute Oceanographic d'Monaco. 2: 1-213

Lindstrom. S.C. 1993. Inter-- and intrapopulation genetic variation in species of Porphyra from British Columbia and adjacent waters. Journal of Applied Phycology. 5:53-62

Linnaeus. C.. 1758. Systema Naturae..., Vol. 1, $10^{\text {th }}$ ed., L. Salvii Stockholm. ii $+824 \mathrm{pp}$

Littler. M.M., Littler, D.S., and Hanisak, M.D. 1991. Deep--water rhodolith distribution. productivity. and growth history at sites of formation and subsequent degradation. J. Exp. Mar. Biol. Ecol. 150:163-182

Lynch, M. 1990. The similarity index and DNA fingerprinting. Mol. Biol. Evol. $7(5): 478-484$ 
Majer, D.. Mithen. R., Lewis. B.G.. Vos. P., and Oliver. P. 1996. The use of AFLP fingerprinting for the detection of genetic variation in fungi. Mycol. Res. 100(9):1107-1111

Markwick. P.J. 1998. Fossil crocodilians as indicators of Late Cretaceous and Cenozoic climates: implications for using palaeontological data in reconstructing palaeoclimate. Palaeogeography, palaeoclimatology, palaeoecology. 137(34):205

Miller. M.P. 1997. Tools for Population Genetic Analysis v. 1.3

Nei. M. 1978. Estimation of average heterozygosity and genetic distance from a small number of individuals. Genetics. 89:583-590

Paul. S.. Wachira. F.N.. Powell. W., and Waugh. R. 1997. Diversity and genetic differentiation among populations of Indian and Kenyan tea (Camellia sinensis (L.) O. Kuntze) revealed by AFLP markers. Theor. Appl. Genet. 94:255-263

Pirrie. D.. Marshall. J.D.. and Crame, J.A. 1998. Marine High Mg Calcite Cements in Teredolites- Bored Fossil Wood; Evidence for Cool Palaeoclimates in the Eocene La Meseta Formation. Seymour Island. Antarctica. Palaios. 13(3): 276

Reid. R.P. and MacIntyre, I.G. 1988. Foraminiferal--Algal Nodules from the Eastern Caribbean: Growth History And Implications on the Value of Nodules as Paleoenvironmental Indicators. Palaios. 3:424-435

Riosmena--Rodriguez, R. 1997. A taxonomic reassessment of rhodolith--forming species of Lithophyllum (Corallinales:Rhodophyta) in the Gulf of California, Mexico. Masters Thesis, San Jose State University. 
Sideman. E.J. and Mathieson. A.C. 1985. Morphological variation within and between natural populations of non-tide pool Fucus distichus in New England. J. Phycol. $21: 250-257$

Sokal, R.R. and Rohlf, F.J. 1995. Biometry. $3^{\text {rd }}$ ed. San Francisco: W.H. Freeman

Sosa. P.A.. Cabrera--Perez, M.A., Garcia--Reina, G. 1996. Genetic variation of Gracilaria cervicornis gametophytes from the Canary Islands. Eur. J. Phycol. $31: 143--147$

Sosa. P.A.. Garcia--Reina. G. 1992. Genetic Variability and differentiation of sporophytes and gametophytes in populations of Gelidium arbuscula determined by isozyme electrophoresis. Marine Biology. 113:679-688

Stearn, C.W. 1982. The shapes of paleozoic and modern reef--builders: a critical review. Paleobiology. 8(3):228-241

Steller, D.L. 1993. Ecological Studies of Rhodoliths in Bahia Concepcion, Baja California Sur, Mexico. Masters Thesis, San Jose State University.

Steller, D.L. and Foster, M.S. 1995. Environmental Factors Influencing Distribution and morphology of rhodoliths in Bahia Concepcion, B.C.S., Mexico. Journal of Experimental Marine Biology and Ecology. 195:201-212

Steneck, R.S. 1986. The ecology of coralline algal crusts: convergent patterns and adaptive strategies. Ann. Rev. Ecol. Syst. 17:273-303

Toomey, D.F. 1975. Rhodoliths from the upper paleozoic of Kansas and the recent--a comparison. N. Jb. Palaont., p. 242-255 
Van Oppen. M.J.H., Oslen, J.L., and Stam, W.T. 1995. Genetic variation within and among North Atlantic and Baltic populations of the benthic alga Phvcodrys rubens (Rhodophyta). Eur. J. Phycol. 30:251-260

Vos. P.. Hogers. R.. Bleeker. M., Reijans. van de Lee. T. Hornes. M.. Frijters. A.. Pot. J., Peleman, J.. Kuiper, M.. and Zabeau, M. 1995. AFLP: A new technique for DNA fingerprinting. Nucleic Acids Research. 23(21):4407-4414

Walker. S. E. and Yamada. S. B. 1993. Implications for the gastropod fossil record of mistaken crab predation on empty mollusc shells. Palaeontology. 36(3):735

Willis, B.L. and Ayre. D.J. 1985. Asexual reproduction and genetic determination of growth form in the coral Pavona cactus: biochemical genetic and immunogenic evidence. Oecologia. 65:516-525

Woelkerling. W.J. 1988. The Coralline Red Algae: An Analysis of the Genera and Subfamilies of Nongeniculate Corallinaceae. Oxford University Press. Oxford. $268 \mathrm{pp}$.

Woelkerling. W.J. 1996. Non-geniculate Corallinales. In: The Marine Benthic Flora of the Southern Australia Part IIIB. Gracilariales. Rhodymeniales. Corallinales and Bonnemaisonales (Ed. By H.B.S. Womersley), 146-282 pp. Australian Biological Resources Study, Flora of Australia Supplementary Series 5. Union offset. Canberra

Woelkerling, W.J. 1983. A taxonomic reassessment of Lithophyllum Philippi (Corallinaceae, Rhodophyta) based on studies of R.A. Philippi`s original collections. British Phycological Journal 18: 165-197 
Woelkerling, W.J. and Campbell, S.J. 1992. An account of southern Australian species of Lithophyllum (Corallinaceae, Rhodophyta). Bulletin of the British Museum (Natural History) Botany Series 22: 1-106

Woelkerling. W.J.. Irvine, L.M., and Harvey. A.S. 1993. Growth-forms in nongeniculate coralline red algae (Corallinales. Rhodophyta). Journal of Phycology: $277-293$

Wood--Jones. F. 1910. On the growth forms and supposed species in corals. Proc. Zool. Soc. London. 518-556

Wray. J.L. 1971. Ecological and geological distribution. In. Geology of Calcareous Algae Notes for a short course), edited by R. Ginsburg. R. Rezak and J.L. Wray. Comparative Sedimentology Laboratory, Univ. Miami. 5.1-5.6

Wright. S. 1951. The genetic structure of populations. Ann. Eugenics. 15:323-354

Yabur-Pacheco. R. 1998. Composicion especifica y por formas de crecimentos de los mantos de rodolitos en el Golfo de California, Mexico. Unpublished Bachelor thesis. Marine Biology Depart., Universidad Autonoma de Baja California Sur. $50 \mathrm{p}$.

Zimmerman, R.C. 1993. Sim 1.01. University of California Regents. 
Table 1. Sequences of primers and adaptors used for AFLP analyses.

Eco RI adaptor

Msel adaptor

EcoRI +3 primers

EcoRI +3 primers

Mse I +3 primers

Mse I +3 primers
5' -CTCGTAGACTGCGTACC-3'

3' -CTGACGCATGGTTAA-5'

5'-AATTGGTACGCAGTC-3'

3'-TACTCAGGACTCAT-5'

E4 5'-AGACTGCGTACCAATTCAATG

F4 5'-AGACTGCGTACCAATTCAAGT

E4 5'-GATGAGTCCTGAGTAATTTG

F4 5'-GATGAGTCCTGAGTAATTTG 
Table 2. Quantity of samples collected, ran and used in statistical analyses. LP-1 samples are from Manto de Diana and LP-2 samples are from Manto de Pepe. PC-1 samples are from Manto de James and PC-2 samples are from Manto de Zachary.

\begin{tabular}{|l|l|l|l|l|l|l|l|l|}
\cline { 2 - 9 } \multicolumn{1}{c|}{} & \multicolumn{4}{c|}{ La Paz } & \multicolumn{4}{c|}{ Punta Chivato } \\
\cline { 2 - 9 } \multicolumn{1}{c|}{} & \multicolumn{2}{c|}{ Foliose } & \multicolumn{2}{c|}{ Fruticose } & \multicolumn{2}{c|}{ Foliose } & \multicolumn{2}{c|}{ Fruticose } \\
\cline { 2 - 9 } \multicolumn{1}{c|}{} & LP-1 & LP-2 & LP-1 & LP-2 & PC-1 & PC-2 & PC-1 & PC-2 \\
\hline $\begin{array}{l}\text { Samples } \\
\text { Collected }\end{array}$ & 25 & 25 & 25 & 25 & 25 & 25 & 25 & 25 \\
\hline $\begin{array}{l}\text { AFLP } \\
\text { Samples } \\
\text { Run }\end{array}$ & 10 & 11 & 6 & 7 & 9 & 8 & 7 & 6 \\
\hline $\begin{array}{l}\text { Samples } \\
\text { Used in } \\
\text { Analyses }\end{array}$ & 10 & 5 & 4 & 4 & 6 & 8 & 5 & 4 \\
\hline
\end{tabular}


Table 3. Similarity values (S) among individuals within populations prior to pooling data.

\begin{tabular}{|c|c|c|c|}
\hline Population & S & SD & $\mathrm{n}$ \\
\hline LP-Fol & 0.78 & 0.12 & 10 \\
\hline LP-Frl & 0.55 & 0.24 & 4 \\
\hline LP-Fo2 & 0.75 & 0.22 & 5 \\
\hline LP-Fr2 & 0.63 & 0.31 & 4 \\
\hline PC-Fol & 0.85 & 0.05 & 6 \\
\hline PC-Fr1 & 0.63 & 0.38 & 5 \\
\hline PC-Fo2 & 0.84 & 0.05 & 8 \\
\hline PC-Fr2 & 0.67 & 0.24 & 4 \\
\hline
\end{tabular}


Table 4. Matrix of similarity values (+/- SD) for within and among population comparisons. An asterisk indicates statistical significance, actual statistical values are in Table 5.

\begin{tabular}{|l|c|c|c|c|}
\hline & La Paz Foliose & La Paz Fruticose & Pta. Chivato Foliose & $\begin{array}{l}\text { Within } \\
\text { Population }\end{array}$ \\
\hline $\begin{array}{l}\text { La Paz } \\
\text { Foliose }\end{array}$ & & & & $\begin{array}{c}0.76 \\
(+/-0.2)\end{array}$ \\
\hline $\begin{array}{l}\text { La Paz } \\
\text { Fruticose }\end{array}$ & $0.60(+/-0.4) *$ & & & $\begin{array}{c}0.57 \\
(+/-0.1)\end{array}$ \\
\hline $\begin{array}{l}\text { Pta. Chivato } \\
\text { Foliose }\end{array}$ & $0.76(+/-0.1)^{*}$ & $0.52(+/-0.1)^{*}$ & & $\begin{array}{c}0.83 \\
(+/-0.1)\end{array}$ \\
\hline $\begin{array}{l}\text { Pta. Chivato } \\
\text { Fruticose }\end{array}$ & $0.38(+/-0.1) *$ & $0.51(+/-0.3) *$ & $0.62(+/-0.6) *$ & $\begin{array}{c}0.61 \\
(+/-0.1)\end{array}$ \\
\hline
\end{tabular}


Table 5. F-Test testing for statistical significance between among and within population variation. $\alpha^{\prime}$ is the alpha used for each successive comparison as outlined in the Dunn-Sidak method.

\begin{tabular}{llllll} 
Source of variation & $\mathrm{df}$ & $\alpha^{\prime}$ & $\mathrm{F}^{\prime}$ & $\mathrm{F}^{\prime} \mathrm{SE}$ & $\mathrm{P}$ \\
\hline LP-Fo v. LP-Fr & 22 & .05 & .176 & .061 & $<.01$ \\
PC-Fo v. PC-Fr & 22 & .03 & .260 & .099 & $<.01$ \\
LP-Fo v. PC-Fo & 28 & .02 & .150 & .024 & $<.01$ \\
LP-Fo v. PC-Fr & 23 & .01 & .243 & .117 & $<.01$ \\
LP-Fr v. PC-Fr & 16 & .01 & .174 & .062 & $<.01$ \\
LP-Fr v. PC-Fo & 21 & .01 & .378 & .064 & $<.01$
\end{tabular}




\section{Figure Captions}

Figure 1. Map of Baja California Sur, Mexico with sampling site enlarged. An asterix represents a sampling site.

Figure 2. Photograph of range of growth-forms found in L. margaritae. Column A consists of fruticose individuals, column B consists of intermediate or hybrid morphologies and column $\mathrm{C}$ contains foliose individuals. Only fruticose and foliose rhodoliths were sampled.

Figure 3. AFLP flowchart.

Figure 4 A.. B. Photograph of samples extracted with guanidine thiocyanate and protease. DNA in the $23-20 \mathrm{~kb}$ range was gel-purified from each sample.

Figure 5. Photograph of AFLP banding profile for samples from La Paz and Pta. Chivato. Lanes 1 and 2 are foliose from $\mathrm{La} \mathrm{Paz}$ and lanes 3 and 4 are fruticose from $\mathrm{La}$ Paz. Lanes 5 and 6 are foliose from Pta. Chivato and lanes 7 and 8 are fruticose from Pta. Chivato. Arrows represent conserved bands.

Figure 6. UPGMA tree using genetic distance defined by Nei (1978). Each node represents genetic distance (D) between populations included in each "branch". Numbers in parenthesis indicate the proportion of similar replicates based on 1000 permutations. 
Figure 1.

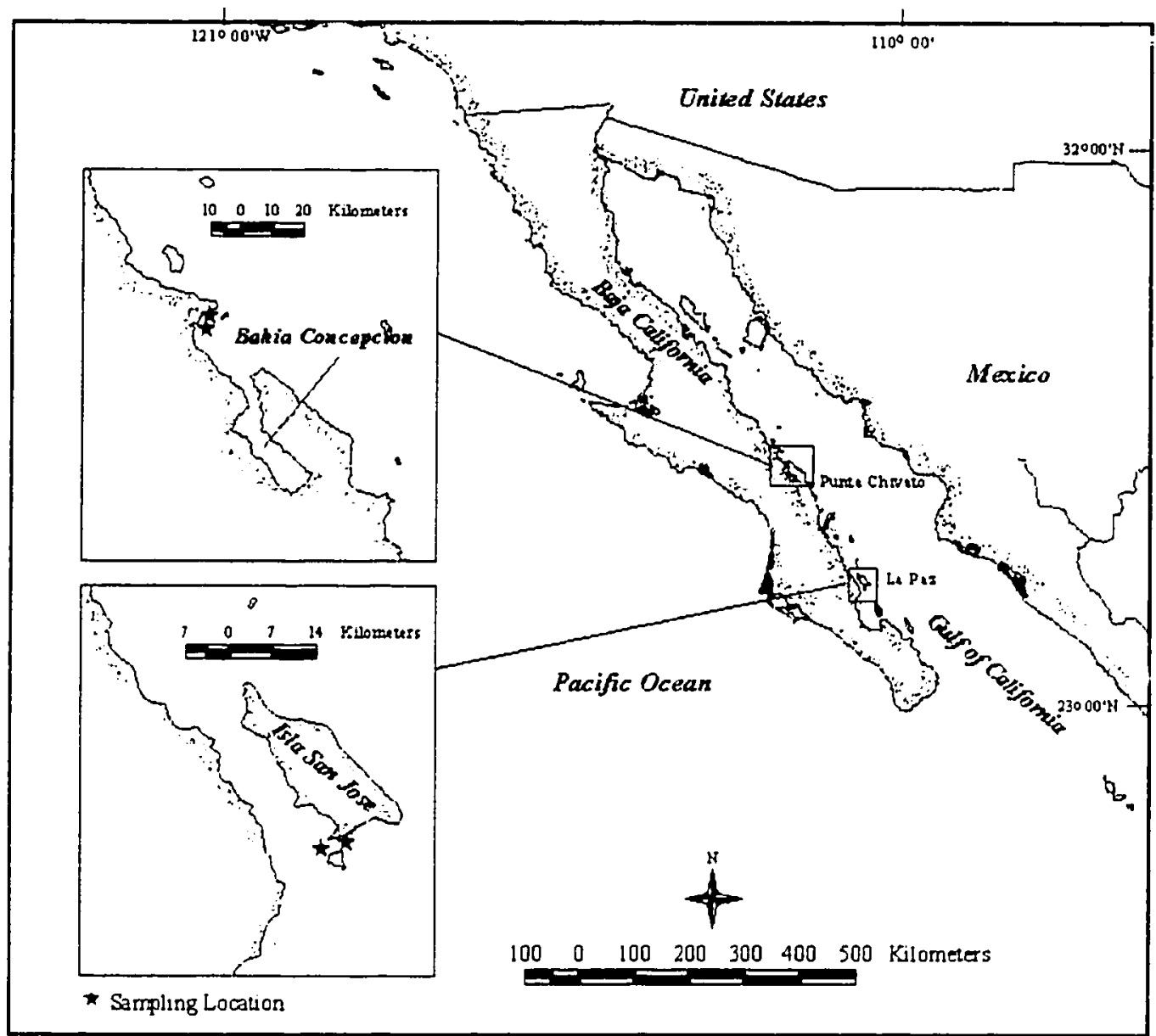


Figure 2.

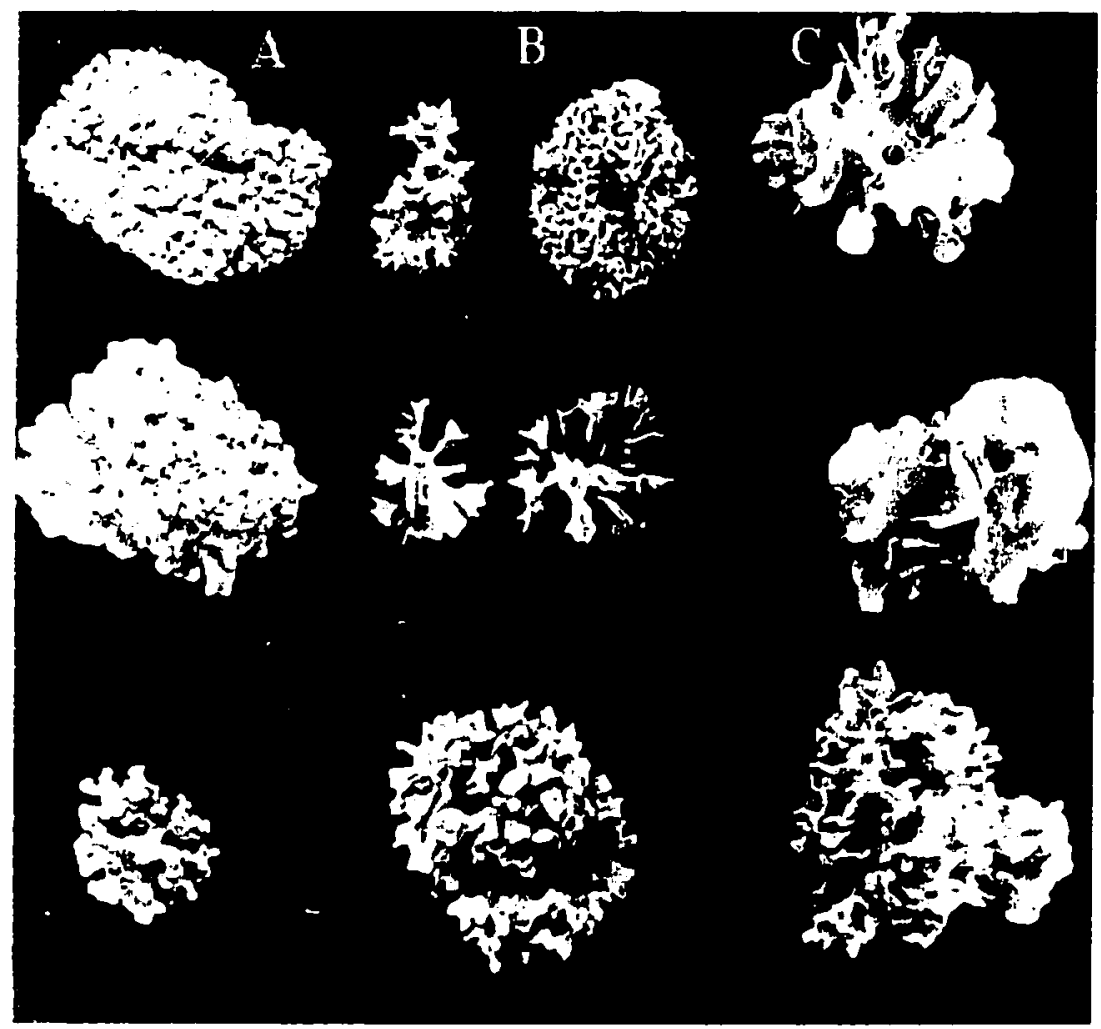


Figure 3.

\section{AFLPs}

\section{Amplified Fragment Length Polymorphisms}

(Vos et al. 1996 NAR 23: 4407)

\section{(A) Digest HMW DNA with \\ EcoRl and Msel}

Ah- ZNNSN . NNAN INNNN . YNNA

(B) Ligate EcoRI and Mssl site-specific adaptors

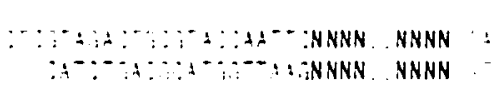

Selective Pre-amplification

(C) EcoRI_x/Msel_y

GACTGGGTACCAATTC:

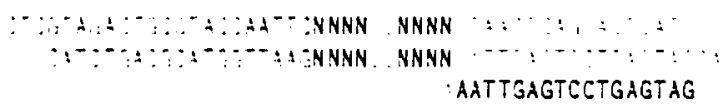

\section{Selective Fingerprinting}

D) Amplification EcoRI_Xnn!:Msel_innn Primers

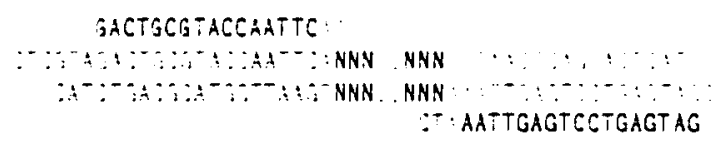

E Gel Analysis
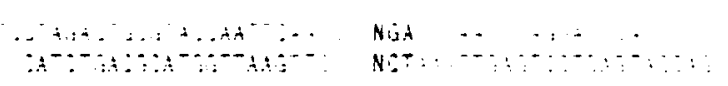

(A)

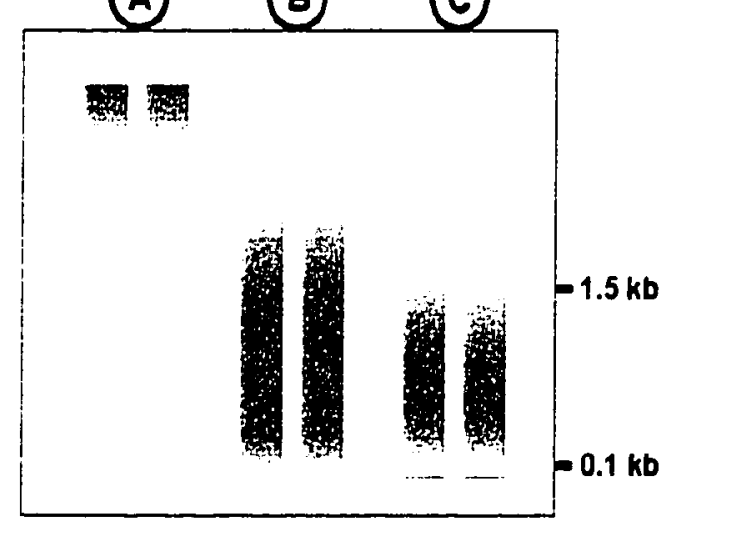

(E)

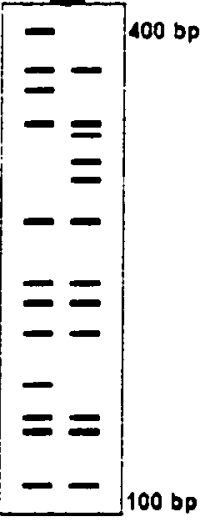


Figure $4 a$.

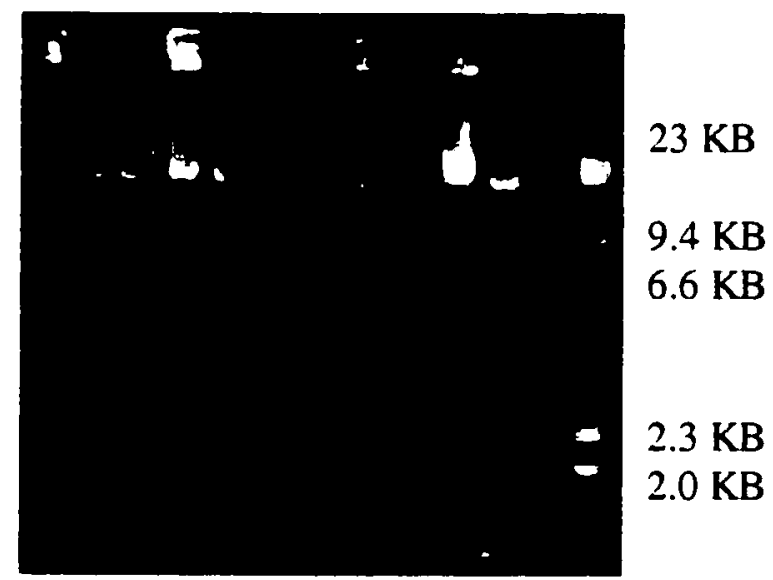

Figure 4b.

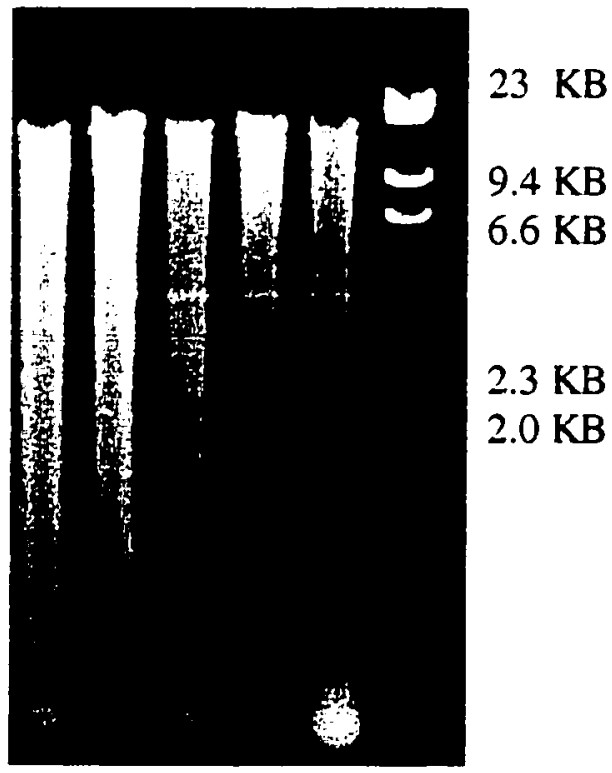


Figure 5.

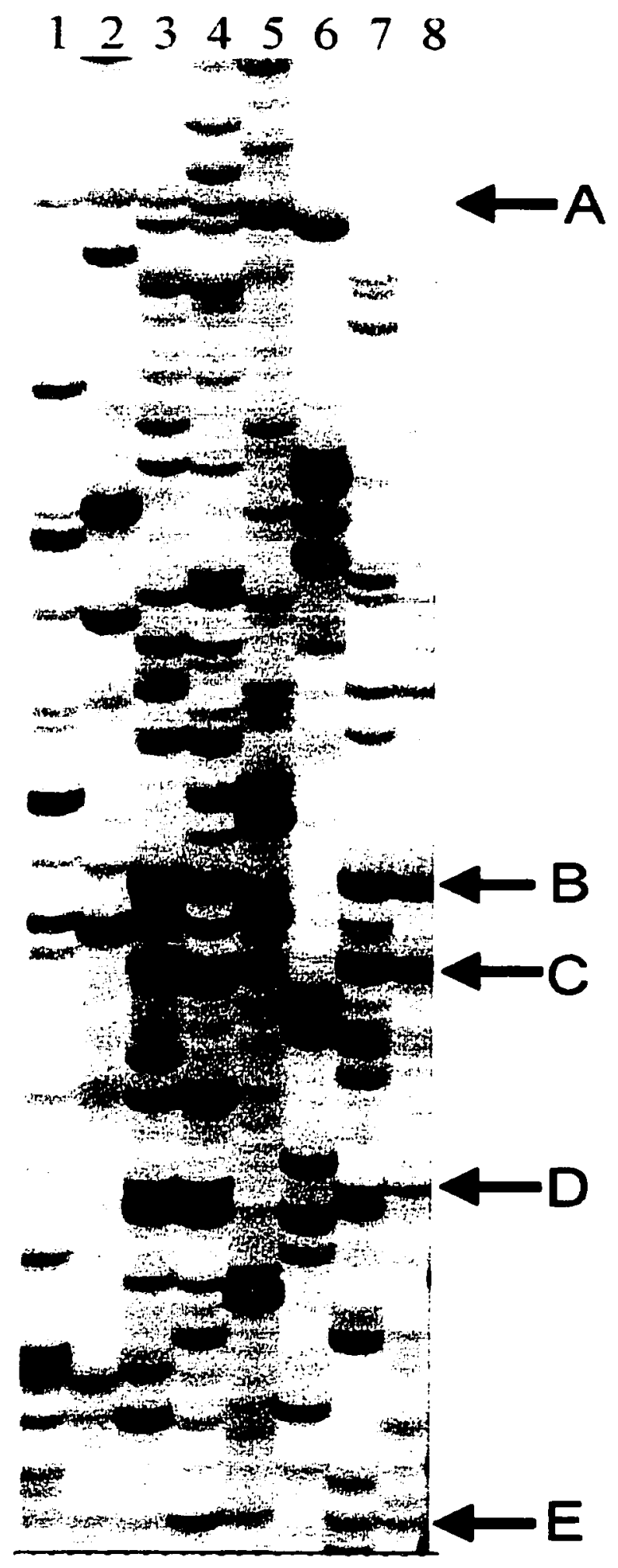


Figure 6.

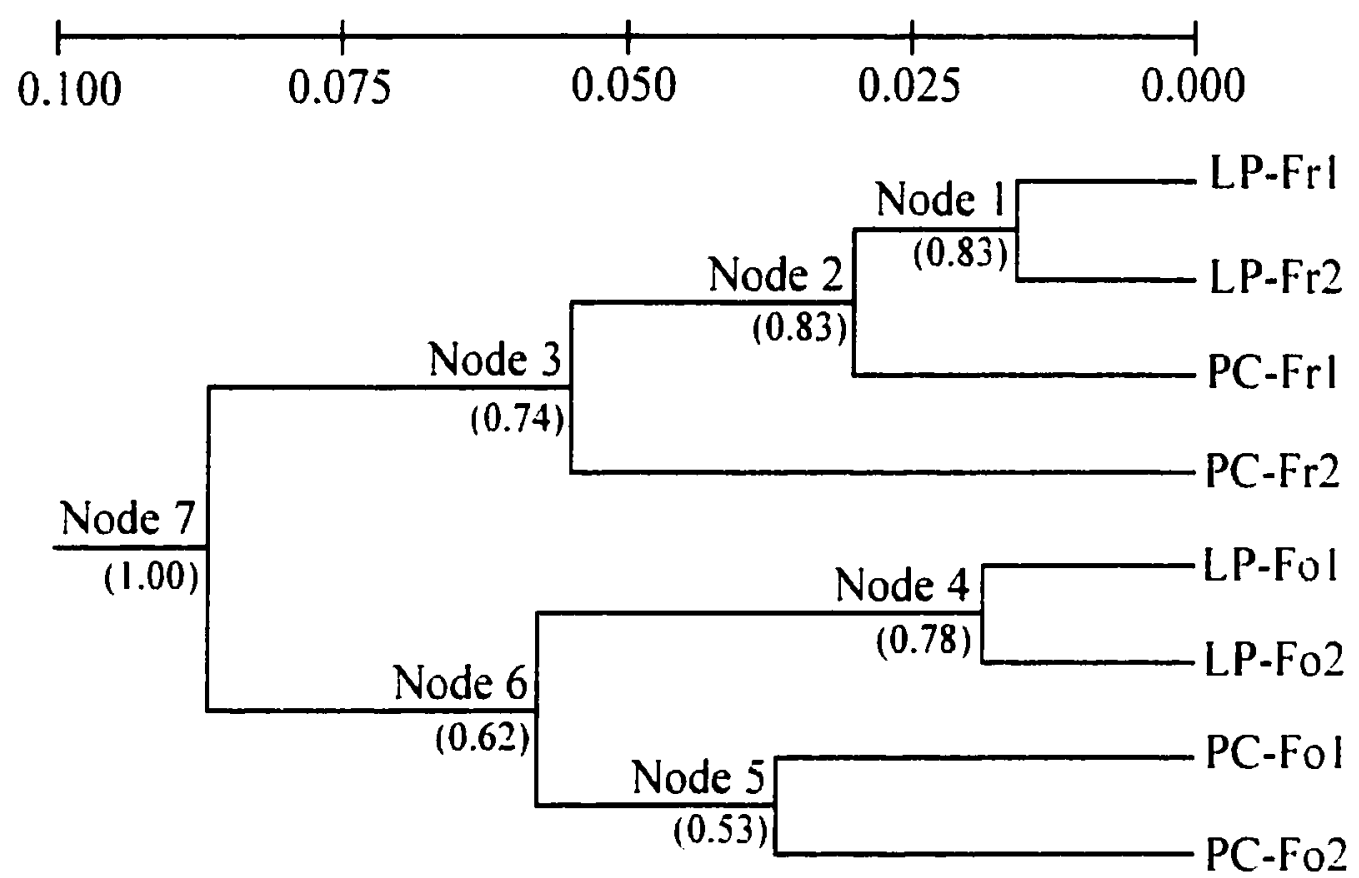

